Papers and Proceedings of the Royal Society of Tasmania, Volume 118, 1984

(ms. received 22. XI.1983)

\title{
PRE-SETTLEMENT EXPLORATION OF TASMANIA AND THE NATURAL SCIENCES: THE CLIVE LORD MEMORIAL LECTURE 1983
}

by N.J.B. Plomley

Wayne Avenue, Sandy Bay, Tasmania

\author{
ABSTRACT
}

PLOMLEY, N.J.B., 1984 (31 viii): Pre-settlement exploration of Tasmania and the natural sciences: the Clive Lord Memorial Lecture 1983. Pap. Proc. R. Soc. Tasm., 118: 6978. https://doi.org/10.26749/rstpp.118.69 ISSN 0080-4703. 13 Wayne Avenue, Sandy Bay, Tasmania, Australia.

The unfolding of knowledge of Australian natural history as a result of the visits of marine explorers is briefly reviewed, particular attention being paid to Tasmania. The importance of the D'Entrecasteaux and Baudin expeditions is stressed, the unique observations of the Baudin expedition on the Tasmanian Aborigines being emphasised.

The observations of exploring expeditions must form the basis for the study of the ecology of the Australasian region because they provide evidence as to the state of the country before it was disturbed by European settlement.

\section{INTRODUCTION}

Exploration had its beginnings in trading and the development of trade routes, and concerned travel by land rather than by sea. For the traveller by land there was the hazard of having to perambulate territories where his reception might be hostile, but the resources needed for his journey were small and he could even carry his trade goods on his own back and walk. The traveller by sea, on the other hand, needed a stout and well found ship which could weather the open sea and sustain a voyage of days, weeks or months, and the perfection of the techniques of sailing and navigation so that a course could be directed from one place to another.

Those most active in diversifying their trading seem to have been the peoples living along the shores of the Mediterranean, and by the beginning of the Christan era they had penetrated not only into Africa but also as far as China along the silk routes. If such traders brought back to their homes any information about the lands they visited, it concerned wonders seen rather than particulars of geography, natural history and the diversity of mankind.

While travel has been stimulated by trading through the ages, over the past two thousand years this primary urge has been overlaid by others. As might have been expected, the first of these was a wish to spread Christianity beyond the confines of Europe, and this wish led to the explorations of the great medieval travellers, of whom Marco Polo was one. A little less than a hundred years later the first of the great sea voyages took place, Diaz rounding the Cape of Good Hope in 1486, Columbus crossing the Atlantic in 1492, and Vasco da Gama sailing round the Cape to India in 1498. For these sea voyages too the stimulus was both trade and the spread of Christianity.

By the beginning of the 18th century, only one large region of the world remained unknown to Europeans, the Pacific. It had been approached both from the east and from the west, the latter as a result of voyages to India by the Portuguese, and subsequently to the East Indies by the Dutch, while the eastern approach followed the incursions by the Spaniards into the Americas. Of these three groups of Europeans, the Portuguese and Spaniards used the conversion to Christianity as a cover for trading ventures, while the Dutch made no bones of their commercial interest. 
As the eighteenth century proceeded, two other groups of Europeans took over from the Dutch, Portuguese and Spaniards. These were the British and French. With their entry on the scene, exploration lost much of its association with religion and the underlying core of economic advantage received instead the concealing wrapping of a disinterested search for knowledge about the whole world, the pursuit of Science.

\section{FIRST RECORDS OF THE NATURAL HISTORY OF AUSTRALIA}

The first records of the natural history of Australia date from a little less than four hundred years ago, when Dutch sailors began to visit the western and northern coasts of Australia. At that time, that is, at the beginning of the seventeenth century, navigation was still an inaccurate science and one difficult to undertake on shipboard. It was therefore necessary for sailors to pay great attention to natural phenomena, and plants and animals, as guides to the nearness of land, even when that land was known to exist. Thus the Dutch, in proceeding to the East Indies, sailed round the Cape of Good Hope and then made an eastwards passage. Often the landfall was the western coast of Australia and the captain would then sail northwards following it until Arnhem Land was reached, from where he would make for Batavia.

The first certain account of a visit to the Australian coast is that of William Janz who came to the western shores of Cape York Peninsula in the Duyfken in 1606 . His visit is of some interest because there was a fight between his men and the Aborigines in which there were deaths on both sides. It was the Spanish explorer Torres who, approaching from the east in the same year, discovered the strait which now bears his name and gave the first recognisable accounts of the animals of the region, mentioning the cuscus, the Torres Strait pigeon and the New Guinea dog.

For the first half of the seventeenth century there are a number of references to Australian animals by Dutch seamen. Many of them were birds, but fishes also were mentioned, and occasionally invertebrates such as shells, and plants. The first observation on the customs of the Australian Aborigines dates from this time, the account of the visit of the Pera and Armhem to the Gulf of Carpentaria in May 1623 recording that the natives used bones, probably the spines of a stingray, as tips for their spears. The records of these seamen relate only to the western and northern coasts of the continent because although Pieter Nuijts visited the southern coast of Australia in 1627 as far east as the islands of St Peter and St Francis, no record of this voyage is known to exist.

It is to the wrecking of Pelsaert's ship Batavia in 1629 on the Abrolhos Islands off the southwestern coast of Australia that we owe the first clear description of a marsupial, the Dama Wallaby ThyZogale eugenii. Pelsaert also mentions the Brush Bronzewing, and refers to termite mounds.

It was not until 1642 that we find any mention of the natural history of the human inhabitants of Tasmania. When Tasman visited the island in November of that year he not only charted the coastline along which he sailed but he recorded events in his $10 \mathrm{~g}$. Unfortunately these records are very brief and not particularly informative. There is the well known comment that though the Aborigines were not seen it was realised that the island was inhabited because of the smoke of fires and the finding of notches cut into the bark of trees for footholds in climbing them. It was stated that stone implements had been used in cutting these notches, so evidently the Dutchmen were well aware that the natives of Australia, of which Tasmania was then believed to be a part, used stone implements - and that the notches were so widely spaced that the people must be either very tall or had some particular means of climbing. Although Tasman makes some reference to Tasmanian animals, it is hard to be certain about their identity.

It was William Dampier who gave what may be thought of as the first clear descriptions of Australian animals, that is, descriptions in words and pictures which attempted to 


\section{N.J.B. Plomley}

distinguish different forms. Dampier visited the Western Australian coast twice, first in 1688 and next in 1699. On his second visit, in his own ship the Roebuck, he made both zoological and botanical collections and also described some of his specimens, with illustrations by an artist he took with him. He also described the Aborigines, and one of his comments about them has some relevance for us in Tasmania. He remarked that the men had undergone a ritual removal of some of their front teeth, and later this comment led to confusion about the occurrence of tooth avulsion amongst the Tasmanians.

In this pre-scientific period, as we may refer to it, there developed an interest in the animals and plants of Australia. However, this interest could not develop very far because there was no way of describing living things except as individual forms, that is, their relationships had not yet been made part of the descriptive process. Such a system for the naming of biological material was made possible by the studies of Linnaeus, who in 1735 published his System Naturae in which a binomial system of nomenclature was propounded. Under this system those characters of an organism were described which were basic to its structure, that is, an organism received two names, genus and species, the first name referring to the basic structures distinguishing it from organisms having a different set of basic structures, and the second to other characters which differed among the members of the genus. This method of naming implied that all organisms were related to one another, some closely others distantly. From 1735, then, we might expect to find not only much greater precision in the description of living forms but a greatly increased interest in surveying the natural history of the world.

\section{STUDIES OF TASMANIAN NATURAL HISTORY}

The stimulation which the study of the natural world received from Linnaeus's system of nomenclature was complemented by interest in an astronomical problem. This was the determination of the distance between Earth and Sun, a computation which was basic to the study of the universe. How to measure this distance had been a problem which had exercised philosophers since antiquity, and during the seventeenth century mathematical and astronomical research led to the idea of calculating it from measurements of eclipses of the sun by certain of the planets, especially Mercury and Venus. It is a characteristic of transits of Venus that they are double events, a first occurrence being followed by a second eight years later.

Scientific interest in transits was first aroused by observations on Mercury in 1631 and on Venus in 1639. The possibility of using transit data for the calculation of the Earth/Sun distance was realised, and methods for doing so devised, largely as a result of observations made by the astronomer Edward Halley on a transit of Mercury which he witnessed at the island of St Helena in 1677. Astronomers were therefore anxious to make measurements when the next transits of Venus were due in 1761 and 1769.

Largely through the enthusiasm of the French astronomer Joseph-Nicolas Delisle, study of the transits of Venus in 1761 and 1769 became matters of world-wide concern and governmental aid, observations being made at a large number of stations in those parts of the world from which the transits could be observed. In several cases the expeditions observing the transits also made detailed studies of the natural history of the places they visited, and some of these were important in relation to the Australasian region. Thus, when the French astronomer Alexandre-Gui Pingre visited the island of Rodriguez to observe the transit of 1761 he also made a biological survey of the island and collected specimens of its unique fauna and flora.

Another expedition of interest to us was that led by Guillaume-Joseph-Hyacinthe-JeanBaptiste Legentil de la Galaisiere. Legentil left France in March 1760 with the object of observing the transit at Pondichery, then a French possession in India. By the time he had reached Ile de France in July of that year Pondichery was under seige by the British. After several changes of plan Legentil eventually attempted to reach Pondichery with a French naval force sent to relieve the city but when on arrival at Male on the Malabar coast of India news was received that Pondichery had been captured by the British, the French ships turned back to Ile de France: on 6 June 1761 Legentil was on the high seas, and of course was not able to make any observations of the transit. Cheated of his reward, Legentil decided to remain in the region for another year to gather data relating to 
navigation and geography, as well as to undertake studies in natural history. His one year stretched out to eight eventually because he stayed on to make observations of the next transit of Venus in 1769. His eight years in the region were extremely fruitful, and he published their results in a massive two-volume work, in which he dealt with a wide variety of topics such as the customs and religions found in India and the astronomy of the Hindus, as well as researches in Madagascar and in the Philippines, the 1atter including studies of the soil and its productions, the ethnology of the inhabitants and a history of the Spanish colony. There were also many studies of natural history and of course determinations of latitude and longitude at each of the places he visited. One comment on his work which I think is of particular interest concerns his regard for native peoples "In his simple manners and absence of pomposity, he showed for the native peoples of every country he visited the most sympathetic understanding".

Study of the observations made of the transit of 1761 did not produce a reliable estimate of the Earth/Sun distance, and so there was wide concern to make a success of the 1769 observations. Not only were more people now interested in the problem, but greater efforts were put into the organisation of expeditions and the development of more accurate scientific instruments for making the measurements. In the discussions involved in preparing for the 1769 transit, the desirability of making observations at stations in the South Seas was emphasised. It was the British who responded particularly to this need, placing the Endeavour under the command of James Cook to observe the transit in Tahiti. Cook and his astronomer Charles Green succeeded in making the necessary observations there on 3 June 1769. Thereafter Cook sailed westwards under instructions to look for and explore the eastern coast of Australia, or New Holland as it was then called. On board the Endeavour were Joseph Banks and Daniel Carl Solander, two men who were to play a most important part in the study of the natural history of the Pacific in general and of Australia in particular.

Having set the scene, as it were, for the real beginnings of the study of the natural history of Tasmania, it is worthwhile to review very briefly those studies in relation to the marine explorers who visited that place before the island was settled by Europeans. Cook himself did not come until 1777, on his third voyage to the Pacific, but Furneaux spent a few days in Adventure Bay in 1773 during the second voyage.

This group of marine explorers comprised Tasman (1-4 December 1642), Marion du Fresne (6-10 March 1772), Tobias Furneaux (10-15 March 1773), James Cook (26-30 January 1777), William B1igh (20 August-4 September 1788), John Henry Cox (3-11 July 1789), William B1igh (9-22 February 1792), Bruny D'Entrecasteaux (23 Apri1-29 May 1792; 22 January-1 March 1793), John Hayes (26 Apri1-9 June 1793), Bass and Flinders (October 1798-January 1799), and Nicolas Baudin (13 January-27 February 1802).

It will be noticed that these visitors fall into two groups. Firstly, there were two expeditions which each stayed some weeks, a total of about ten weeks by the D'Entrecasteaux expedition and about seven weeks by the Baudin expedition. Hayes stayed at the Derwent about six weeks in 1793, but unfortunately there is no record of what he did there except for his map. Bass and Flinders circumnavigated the island in 1798/99, a voyage which involved no more than occasional landfalls with short periods on shore. The other group comprises six visitors who stayed an average of eight days each, that is, they had come for little more than to replenish wood and water, and the time devoted to collecting specimens of natural history or making observations on the Aborigines was very limited indeed. It might also be noted that all visitors except Tasman, Marion du Fresne and Cox, who spent all their time at or in the neighbourhood of Maria Island, confined their visits entirely or largely to the one small region, Bruny Island and the lands bordering the Derwent River.

The collections made by the "wood and water" visitors were small. Tasman seems to have collected nothing, and Marion du Fresne and Cox only she1ls. Furneaux's acquisitions were probably little more than the specimens of the Grey Goshawk (Accipiter novaeholZandiae) and Crested Penguin (Eudyptes cristatus) which he took to New Zealand for the Forsters, drawings of them by George Forster being now in the British Museum (Natural History).

There was not an official naturalist with Cook on his third voyage and the collecting of specimens and recording of observations depended largely upon his friend Surgeon William 
N.J.B. Plomley

Anderson. Some of Anderson's collections reached England after the voyage (others were, and may still be, in Russia and in Vienna). Among Anderson's papers there are descriptions of several Tasmanian animals, and John Webber and William E1lis painted some of them. During this visit the first words of Tasmanian language were recorded.

Whatever Bligh may have collected during his visit in the Bounty in 1788 , collections which probably comprised little more than plants and shells, was almost certainly lost as a result of the mutiny, but during his second visit (actually his third visit because he had first come with Cook in 1777 as master on the Resolution) specimens were collected and George Tobin, Third Lieutenant on the Providence, painted a number of them, including the echidna, birds (Blue Wren, Tasmanian Robin) and some fish.

Lastly, we may mention the visits of Bass and Flinders to the Furneaux Islands and their circumnavigation of Tasmania. None of their collections seems to have survived the stresses of their voyages except for a wombat which Flinders caught when he visited Preservation Island in the autumn of 1798 to rescue the survivors of the wrecked Sydney Cove and took back to sydney alive. This specimen, preserved in spirits, was sent to Sir Joseph Banks, destined for the collections of the Philosophical Society of Newcastleon-Tyne. Bass also sent Banks skins and a skull of wombats collected at the Furneaux Islands in October 1798. The visits to Bass Strait by Bass and Flinders also resulted in the recording of information about the mutton birds and penguins seen there, as we 11 as the seals.

\section{THE VISITS OF D'ENTRECASTEAUX AND BAUDIN}

It has been seen that the observations made by the short-visit expeditions to Tasmanian shores up to the time of settlement in 1803 were not particularly productive of information about the natural history of the island. At most a few random specimens were collected and some meagre information about the country was obtained.

Quite different, however, were the visits of Bruny D'Entrecasteaux in 1792 and 1793 and of Nicolas Baudin in 1802. These were visits made for the purpose of investigating the natural history of Tasmania and it is to them we owe our first real knowledge of it, with in addition their accounts of the Tasmanian Aborigines, by far the most interesting and most instructive of all those we have of these people in their natural condition. And if these two results of their visits were not enough, we must add the very high quality of the charting of the Tasmanian coastline which was carried out.

In order to understand the work of the French and British expeditions we must compare their organisation. From the middle of the 18th century, official expeditions of discovery included among their objects the gathering of scientific information. This change of emphasis away from the purely commercial was a consequence of the exhortations of Charles de Brosses, whose Histoire des navigations aux Terres Australes, published in 1756, forcefully urged the importance of this aspect of a voyage of discovery. Of course treasure and commercial and political advantage were never dropped from view, but the charting of coastlines, the improvement of navigation and the scientific study of countries visited now became activities of very great importance in the work of expeditions. One has only to read the accounts of the voyages of Cook, D'Entrecasteaux, and Baudin to realise that. Yet there was a fundamental difference between the British and French expeditions in regard to the organisation of the scientific work. This is perhaps best shown by comparing Cook's three voyages to the Pacific with those of La Perouse, D'Entrecasteaux and Baudin. With the Cook voyages there was no organised study of the natural sciences but a haphazard and whimsical attack upon it, so that on the first voyage the scientists were Banks and Solander, both primarily botanists; on the second voyage the two Forsters; and on the third voyage there was not an official scientist but the Surgeon, William Anderson, had to do duty for one. In spite of this the scientific work carried out by Banks and Solander and by the two Forsters was superb and of lasting importance. The French exploring ships, on the other hand, carried teams of scientists, so that the main subjects of study - geology, botany and zoology - were fully covered. Thus, with La Perouse there were a botanist, three zoologists and a mineralogist, as well as three artists and a gardener; with D'Entrecasteaux there were five naturalists, the artist Piron and the gardener La Haye; and with Baudin there were three botanists, five zoologists, two geologists, four artists, and 
a gardener and his four assistants (a number of the scientists setting out with Baudin had, however, either defected or retired through illness or were dead before his expedition reached Tasmania). The making of charts and the determination of latitude and longitude were the responsibility of naval officers attached to the various ships and were separate from the scientific work.

Not only did the French expeditions carry a wide range of scientists, but the 1 ines upon which they were to work were laid down for them before departure. Here was another important difference between British and French procedures. Both governments took the advice of their learned societies in making arrangements for the scientific studies to be made part of the work of their expeditions, the British Government being advised by the Royal Society of London, and the French Government by the Institut de France and the Museum d'Histoire Naturelle, but while the Royal Society attended only to matters related to the selection of staff, the Institut and Museum also drew up detailed instructions for the work of the French scientists. Of course the naval authorities of both countries issued detailed instructions as to the conduct and procedure of those on board their ships, dealing with such matters as the places to be visited and the routes to be followed, the health of those on board, their food, the conduct to be observed when making contact with other peoples, particularly native peoples, and so on; but even in these matters the British instructions were far more general and left more to the initiative of their captains, while the French tried to cover possible eventualities in their instructions and even laid down a timetable of arrivals and departures at each place to be visited, programmes which were found to be quite unrealistic in practice, as happened with Baudin.

The scientific instructions issued for the French expeditions were also unrealistic in regard to the amount and kind of observations which were required of the scientists, being much too detailed for situations in which an observer had to do the best he could under the conditions actually experienced, yet these instructions do give a picture of the stage of development of particular sciences and the lines along which scientists were thinking at this period. I shall not attempt here to discuss these instructions as they related to geology, botany and zoology, because I want to go into some detail about the history of one special aspect of the natural sciences - the study of man.

The work of the naturalists of the D'Entrecasteaux and Baudin expeditions in Tasmania ranged widely. The principal scientists involved were Labillardiere who came with D'Entrecasteaux, and Peron and Leschenault who came with Baudin. Their collections together with those of other scientists and ship's officers were both important and extensive. It has been reported that the work of the Baudin expedition on the coasts of Tasmania and the Australian mainland resulted in sending back to France more than 22000 specimens, comprising dried plants and preserved animals, ethnological material, living animals and plants, mineral specimens and so on. These collections provided material for study for many years, so that we find that the first description of a number of Tasmanian species was one outcome of these two expeditions.

The botanical work of the D'Entrecasteaux and Baudin expeditions was undertaken by Labillardiere and by Leschenault. Labillardiere's work was published in two large volumes in 1804 and 1806, illustrated by a number of plates, descriptions of a few Tasmanian species having appeared earlier in Labillardiere's general account of the voyage of D'Entrecasteaux which was published in 1802. Leschenault's botanical studies on the Baudin expedition did not appear in book form, except for a memoir on the botany of the Australian region which appeared in the VOYAGE, but were published in a series of memoirs in the Annales of the Museum d'Histoire Naturelle in Paris in 1810/11. The first comprehensive British collections of plants from Tasmania and the islands of Bass Strait were those made by Robert Brown between 1802 and 1804, and were described in his PRODROMUS FLORAE NOVAE HOLLANDIAE ET INSULAE VAN-DIEMEN (1810).

The zoological work of the D'Entrecasteaux expedition also fell largely on the shoulders of Labillardiere, and we find in the VOYAGE mention of a number of Tasmanian species: birds, including the Black Swan, mammals, fish and so on. Many of the specimens collected were later described in the literature, for example, the insects were named by Fabricius. 


\section{N.J.B. Plomley}

In keeping with the huge number of specimens collected during the Baudin expedition, we find an extensive literature dealing with the description of Australian and Tasmanian species. By the time the expedition had reached Tasmania in January 1802, the naturalists had been reduced to two, Peron and Leschenault - Bory de Saint Vincent, Delisse, Dumont and Michaux had either defected or had been left ill at Ile de France on the voyage out; Riedle, gardener-botanist, died at Timor; the zoologist Levillain died at sea shortly after the expedition left Timor on its way to Tasmania, and Mauge.was to die at Maria Island during the Tasmanian visit. The two geologists, Bailly and Depuch, went through the whole Australian experience, though Depuch was to die at Ile de France on the voyage home. Of the five artists, three left the expedition at Ile de France on the voyage out, and only Lesueur and Petit remained with it for the whole voyage. It says much for Peron and Leschenault that they not only completed the voyage but made such huge collections. It must be added that the leader of the expedition, Nicolas Baudin, was also interested in natural history and made collections. This was no new interest for him because he had already been employed in the West Indies making natural history collections, mostly of plants and insects, for the Emperor of Austria and for the Museum d'Histoire Naturelle in Paris. Several of his officers were also interested in natural history, made collections, and assisted the naturalists.

Not only were Peron and Leschenault active in collecting natural history material, but they absorbed themselves in describing it. Leschenault did not return to France with the expedition but remained in the East Indies for quite a time collecting plants there. When he did return to France he worked on all these collections at the Museum d'Histoire Naturelle in Paris. Peron was not entirely alone as zoologist, the natural history artist Lesueur collaborating with him in a great deal of his work. Peron's interests were wide ranging, covering most groups of animals. He published descriptions of coelenterates; his notebooks contain descriptions of reptiles, amphibians and fishes, including new species, as well as many invertebrates, and only birds received little attention from him, though specimens were collected throughout the voyage; he published memoirs on the temperature of the sea, on the zoology of the Australian region, on seals and their relatives, and on dysentery, and he reported at length on the physical features, geology and natural history of Maria Island and of other places. He even made a collection of lichens in Tasmania!

Three other points should be mentioned before dealing with the anthropological work of the Baudin expedition. These are the charting and geographical work, the geological observations, and the work of the artist-naturalist Charles-Alexandre Lesueur. The basic charting of southeastern Tasmania had been carried out by Beautemps-Beaupre during D'Entrecasteaux's visits in 1792 and 1793 . Baudin's marine surveyors, Pierre Faure and Charles-Pierre Boullanger, together with Louis de Freycinet, one of the officers on the Naturaliste, extended and corrected Beautemps-Beaupre's charts of southeastern Tasmania, and in addition surveyed the eastern and northeastern coasts of the island, including the southern part of the Furneaux Islands and Port Dalrymple, and the far northwestern coast, the Hunter Islands and King Island.

Geological observations were undertaken by Louis Depuch and Charles Bailly, and among the records of the expedition there is a catalogue of mineral substances collected by Bailly. Peron was also interested in geology and in his report on Maria Island he deals with the geology of the region. To Peron is also due the first reference to Tasmanian fossils, when he mentions that he collected fossil shells in marine deposits lying between the Derwent and Goat Hill.

Lastly, some mention must be made of the natural history drawings and paintings of Lesueur. These were of a standard which has hardly been surpassed, and he executed literally hundreds of them. Few have been published, but the bulk of Lesueur's work is still in existence, largely in the collections of the Museum d'Histoire Naturelle at Le Havre. These superb drawings and paintings certainly should be published, in spite of the difficulties in reproducing them in the very fine detail and delicate colouring of the originals. 
At least from the time of Cook, the leaders of official expeditions to the Pacific received instructions "to observe the genius, temper, disposition and number of the natives, and endeavour by all proper means to cultivate a friendship and alliance with them", and such instructions were given to both the British and French explorers in almost identical terms.

It will be convenient to consider the observations made on the Tasmanian Aborigines by the marine expeditions as falling into two groups: one, the wood-and-water visitors and the other those of the D'Entrecasteaux and Baudin expeditions. The wood-and-water visitors were Tasman, Marion du Fresne, Furneaux, Cook, Bligh and Cox. All of them made useful comments on the people they saw, but in no case were the observations sufficiently prolonged or recorded in enough detail to obtain any but scraps of information about the Aborigines.

Before dealing with the impressive observations made by the D'Entrecasteaux and Baudin expeditions, it will be as well to take a look at the state of anthropological knowledge during the second half of the 18 th century. As a scientific study distinct from the curious tales of travellers concerning the peoples of the Earth, anthropology came into its own with the work of Johann Friedrich Blumenbach (1752-1840), Professor of Comparative Anatomy at Gottingen, who from the mid-1770's carried out pioneer studies on the varieties of man. One of those influenced by him was Johann Reinhold Forster (17291798) who sailed with Cook on his second voyage to the Pacific, whose peoples he was to describe in considerable detail, providing a body of information about them which has scarcely been surpassed.

Blumenbach's work exerted considerable influence on explorers and travellers who were interested in the study of man, and this can clearly be seen in the instructions issued for the scientists of the French expeditions to the Pacific. La Perouse was the first: he was instructed to report not only on a number of matters which Cook had dealt with incompletely but also to make a wide range of other enquiries. It is understandable that it was the medical men and not the zoologists who were to concern themselves with the study of man: in the instructions given the scientists only human anatomy was mentioned, attention being drawn to the need for observations on the skeleton of man, the proportions of the body, age at puberty and the duration of life. On the other hand, the instructions given to the medical officers asked for a wide range of information about human anatomy and physiology, hygiene, disease, materia medica and surgery. In all this, however, the social organisation of native peoples received no mention.

When D'Entrecasteaux left France in September 1791 on his voyage in seach of the missing La Perouse, the scientific instructions issued for the voyage were very much like those given to La Perouse. It seems, however, that while still emphasising the importance of Blumenbach, that is, observations on comparative anatomy, there were also to be enquiries into the social organisation of native peoples. Some enquiries dealt also with matters which might be of use to Europeans, for example, the botanists were asked to note what species of plants were used in the manufacture of cords and string, and whether such plants could be grown in the West Indies, that is, in the French colonial possessions there.

For the observations on the Tasmanian Aborigines made by the D'Entrecasteaux expedition we must depend at present largely on Labillardiere's account of the voyage (1802) and to a less extent upon that published by Rossel (1808), one of the naval officers. Unfortunately, no one has yet examined the extensive manuscript records of this expedition. My own preliminary study of them has shown that they contain a great deal of information which is not to be found in the published accounts and which is of considerable value.

When the Baudin expedition came to be organised, the instructions issued for the study of man covered a much wider range than previously. They included a memoir by Joseph-Marie Degerando entitled "On the observation of savage peoples." Degerando's thesis was that the proper way to study man was to observe his whole way of 1 ife, and to do this the observer must first learn the language of the people he was studying. Only in this way 


\section{N.J.B. Plomley}

could he come to know them thoroughly, both individually and as a community. It was a brilliant idea and the basis of modern methods of studying native peoples, but it was to be 150 years before it was put into practice. It was also a methodology which was quite impractical in respect to an expedition such as Baudin's which stayed for only a short time in any one place and also had to deal with a wandering people. The long association needed to gain an adequate knowledge of the language and to study a community in depth was just not possible and it is no wonder that the Baudin expedition followed the old routine of casual observation, with remarks upon the physical characteristics of the Aborines and their manufactures and way of life. Peron did not even apply to his observation of the Aborigines the same level of scientific exactness which he gave to his studies of natural history, so that he failed to enquire systematically into any matter concerning them. Others on the ships did better, for example, Baudin, the Commander. Peron, did however, perform one great service to studies of the Tasmanian Aborigines. He showed them to us in his writing as a living people with such fascinating descriptions as that of Oure-Oure, the young woman he met with her family at Port Cygnet, Arra-Maida whom he met in company with a number of other women on North Bruny, and the party of men he met on Maria Island, an encounter during which tension was high on both sides.

From the records of all the marine expeditions which visited Tasmania before the island was settled by Europeans, we can build up a picture of the characteristics, manufactures and way of 1 ife of the Aborigines. This record is very incomplete but without it we would know almost nothing about the living people who were the original inhabitants of this island. Of all these records only those of the D'Entrecasteaux and Baudin expeditions provide us with any real information about the people, because they were the only ones to stay any length of time. All other explorers stayed too short a time to make anything more than casual observations. And this body of observation gains importance in view of the lack of information about the living people to be found in the records of the settlers, excepting only the journals of G.A. Robinson.

The sorts of information about the Tasmanian Aborigines to be gained from the records of the pre-settlement explorers covers a wide range - physical characteristics, population structure, sickness and injury, dwellings, weapons, implements and manufactures, fire making and fire setting, food and its preparation, language, social organisation and customs, and the interactions of Aborigines and Europeans. As would be expected from the brief contacts between the Aborigines and the wood-and-water visitors, their records are scrappy and often indefinite, but added together they do provide worthwhile information. It is only when the records of the D'Entrecasteaux and Baudin expeditions are studied that any real picture of the living people emerges, but even that picture is at present incomplete because the D'Entrecasteaux records have not yet been examined in detail. The D'Entrecasteaux records gain importance from the fact that the members of this expedition could observe the living people at their camping places, whereas Baudin and his people could not do so because of the suspicions held by the Aborigines about the intentions of the Europeans, an attitude which had developed since the visit of D'Entrecasteaux because of the incursions into the region by 1802 of sealers and kangaroo hunters from Port Jackson.

Perhaps the most striking impression to be gained from the Baudin records is that at the time of this visit the Tasmanian Aborigines were still a normal living people. They showed no signs of decline or degeneration, a view emphasised by the large number of children among them, as well as by the absence of evidence of disease. The technology of the people was simple but it was quite adequate to support active living in the Tasmanian environment. The records provide clear information about many aspects of this technology, though unfortunately not all, for there are a number of points upon which further information is needed, and could have been provided if Peron has been as diligent in recording anthropological data as he was in describing the fauna of Tasmania. It must be remembered that the people whom Baudin was observing were living by the sea, so statements about their food relate almost wholly to the products of the sea and there are few references to foods obtained from the land.

The want of a common language, so that gesture had to be the means of communication, was the real obstruction to mutual understanding between Frenchmen and Aborigines - as Degerando had realised - and so there is little information in the Baudin and other records 
about the social structure and culture of the Tasmanians. It seems that their social organisation was of the simplest, little more than assemblages of families. That they recognised group relationships is shown by the patterns of scarification with which they adorned their bodies, yet they seem not to have had chiefs in the political sense, only leaders to whom they deferred - perhaps the term seigneur would designate these individuals suitably. It seems that there were territorial limits for the activities of the various bands but that a territory was by no means an exclusive property, because travel across territories seems to have been freely allowed, witness the meeting with the Bruny Islanders on the mainland shore opposite Maria Island, and the absence of injuries due to warfare from the bodies of the men.

That the Tasmanians had a strong religious life is made clear from the structure of their tombs, two of which were found on Maria Island. The importance of funerary procedures is shown particularly by the exact form of the tombs and by the markings on the bark covering, which were similar in pattern to the scarifications with which they adorned their bodies.

It seems fitting to conclude a Clive Lord Memorial lecture with some general remarks on the study of the natural history and original inhabitants of Tasmania. As a basis for any studies of natural history today, every attempt should be made to place the present in the context of the past. For a knowledge of the past, at any rate that recent past out of which the present has developed, we must go to the records of the explorers who saw the country before it was occupied by the invading Europeans. The use of an explorer's records is usually difficult: scribbled notes, localities not stated with sufficient precision for clear identification, the record written in a language foreign to the student, the text overwritten and difficult to decipher. Yet the labour of untangling meanings and the boredom of making one's way through seeming endless irrelevancies, usually produces in the end information which is of great value and worth all the time spent on the work. And if the written record is supplemented by a pictorial record, however crude, its value is enhanced.

While the above remarks record my experience with the records of the marine explorers, they apply generally to the records of all explorers, because we need information about the whole country, not just its seaboard as revealed by the generality of marine expeditions. Those who study the Tasmanian environment as well as those who are interested in the larger Australian environment should examine the records of all the explorers of the country, whether they may have been making an official exmaination of some unknown region or just looking for new grazing land. And for information akout the Aborigines, an explorer's records are often of the greatest value, providing perhaps the only information about the life of people who have now vanished. So far as the Tasmanian Aborigines are concerned a thorough examination of the D'Entrecasteaux record is urgently needed.

\section{BIBLIOGRAPHY}

Note: The sources upon which this study have been based can most usefully be indicated by citing a few basic books. In them detailed references will be found to all the topics dealt with here.

Cary, M. and Warmington, E.H., 1963: THE ANCIENT EXPLORERS, Penguin Books.

Plomley, N.J.B., 1983: THE BAUDIN EXPEDITION AND THE TASMANIAN ABORIGINES, 1802, Blubber Head Press, Hobart.

Whitley, G.P., 1970: EARLY HISTORY OF AUSTRALIAN ZOOLOGY, Royal Zoological Society of New South Wales.

, 1970: MORE EARLY HISTORY OF AUSTRALIAN ZOOLOGY, ROyal Zoological Society of New South Wales.

Woolf, H., 1959: THE TRANSITS OF VENUS, Princeton University Press. 